\title{
FINANCIAL FEASIBILITY ANALYSIS OF ORGANIC VEGETABLE FARMING AT CV. RAHAYU IN VILLAGE OF SIDERA SUB- DISTRICT OF SIGI BIROMARU REGENCY OF SIGI
}

\author{
Ferdison S. Mantende ${ }^{\text {I) }}$, Marhawati Mapatoba ${ }^{2)}$, Abdul Muis ${ }^{2)}$ \\ ${ }^{1)}$ Agribusiness Faculty of Agriculture University of Tadulako, Palu. Email :Ferdisonmantende@yahoo.com \\ ${ }^{2)}$ Faculty of Agriculture. University of Tadulako. Palu. Email :Wati_Chairil@hotmail.com \\ dan Email : abdulmuis.oke11@gmail.com
}

\begin{abstract}
This research aimed to analyze the financial feasibility of organic vegetable farming at CV. Rahayu. This research conducted in Sidera, Subdistrict of Sigi Biromaru, Regency of Sigi on December 2016 to January 2017. The respondents were purposively determined. Data was analyzed using financial worthiness analysis employing with 4 indicators: Net present value (NPV), net benefit cost ratio (Net B/C), internal rate of return (IRR), and Payback Period (PP). The results of this research indicated that the NPV during the period 2014 to 2018 was IDR 543.674.792; the net B/Cwas 1,65, the IRR was 35,09\%, and the PP was 2 years and 3 months. The results of the calculationusing sensitivity analysis in the organic vegetable farming company at $\mathrm{CV}$. Rahayu by assuming the organic vegetables attacked by the pests and diseases were a decreased 33 percent from total production with the acquisition of NPV decreased to IDR 8.587.415, Net B/C decreased to 1.01, IRR decreased to 12.42 percent, Payback period became 3.6 years. In the other hand, NPV decreased to IDR 7,276,181, Net B/C decreased to 1.01, IRR decreased to 12.36 percent, payback period became 3.6 years if the assume was an increased production cost until 74 percent. These values financially show the farming at CV. Rahayu is well worth to effort. These results indicate that financially, CV. Rahayu is very feasible to operate.
\end{abstract}

Keywords: CV. Rahayu, Financial Feasibility, Organic Vegetable.

\section{INTRODUCTION}

Organic farming is the answer to the green revolution promoted in 1960 that lead to the reduction of soil fertility and environmental destruction due to uncontrolled use of fertilizers and chemical pesticides. Agricultural systems based "High input energy" such as chemical fertilizers and pesticides could damage soil that eventually could decrease soil productivity, thereby organic farming developed. Organic farming has been known in a long time ago. Actually, since the science of planting had known to man, all donetraditionally by using natural ingredients. The management of organic agriculturebased on the principles of health, ecology, justice, and protection. (Mayrowani, 2012).

The food crops sub-sector is one of the subsectors which is supporting the agricultural sector, the performance of subsector categorized as good which indicates the strengthof supply-side encouragement marked positive (Yantu, et al, 2008). Agricultural development in Central Sulawesi directed to increase production and income of farmers through the program of increasing unit production of land area, improvingquality and process production of a commodity. 
Table 1.Types Of Vegetables Produced By The Company Of CV. Rahayu.

\begin{tabular}{ccc}
\hline No & Vegetables & Market Goals \\
\hline 1 & Kale & TRANSmart,Hypermart,swalayan \\
2 & Red Spinach & TRANSmart, Hypermart,swalayan \\
3 & Okra & TRANSmart, Hypermart,swalayan \\
4 & Mustard & TRANSmart, Hypermart,swalayan \\
5 & lettuce & TRANSmart, Hypermart,swalayan \\
\hline
\end{tabular}

Source: Primary data after processed, 2017.

Central Sulawesi has nineteen types of vegetable crops, they are ranging from leek, potato, cabbage, kale, and others. In 2014, among nineteen types of vegetable crops which have the largest production was tomato vegetable that reached 10.731 Tons, with the widestof harvested area until 2.137 Ha. According to productivity, among the nineteen vegetable crops which have the largest productivity was cabbage plant with $235.74 \mathrm{~kW} / \mathrm{Ha}$ (BPS, 2015).

$\mathrm{CV}$. Rahayu is the first company engaged in organic vegetable cultivation in the City of Palu. The Company located in Sidera Village, Subdistrict of Sigi Biromaru, Regency of Sigi, it produces the commodities that the market wants. The types of organic vegetables were marketing directly in market-oriented such as TRANSmart (Carrefour), Hypermart, and some shopping malls in the town. Because, the prices of organic vegetables relatively expensive, most of the consumers of organic vegetables are people who have incomeabove average. Types of vegetables produced by the company are 5 types of vegetables could be seen in Table 1 .

Sustainable and competitive agriculturaldevelopment which aimed to maintain the sustainability of the ecological environment (the internal and external communities of the company) which is required to prepare a plan and strategy. Based on the description of the explanation, it is stated clearly nowadays people's awareness to consume healthy food like the organic vegetable is still relatively low, and the price of the organic vegetable commodity is very high especially in Palu city. The high prices of these commodities lead to low market demand. This condition shows financial feasibility analysis is very relevant to be done atCV. Rahayu. The formulation of the problem are : 1). Does organic vegetable farming at CV. Rahayu financially feasible? 2). How is sensitivity level of organic vegetable farming atCV. Rahayu?

The objectives of this study are 1). To find out the financial feasibility of organic farming at CV Rahayu.2). To know the sensitivity level of organic vegetable farming at CV. Rahayu.

\section{RESEARCH METHODS}

Place and Time. This research conducted at CV. Rahayu in Sidera Village, Subdistrict of Sigi Biromaru, Regency of Sigi. The determination of this research location ispurposivelydetermined by consideration, this farming is the only farm who produces organic vegetables for Palu City. The research hadbeen conducted for two months, December 2016 to January 2017.

\section{Determination Method of Respondents.} The respondents were chosen purposively. The respondents were chosen from the internal parties of the company with the number of respondents consisted of six people, including with the first person was the company leader, the second respondent was a treasurer, the third respondent wasmarketing manager, the fourth respondent wasa supervisor of the factory, the fifth respondent wasproduction manager, the last respondent was planted cultivation manager.

Methods of Collecting Data.The implementation of this study used the primary data and secondary data. Primary data obtained from the results of observation and direct interviews to respondents who assisted with a list of questions (Questionnaire). Secondary data collected from various libraries that support the research activities of relevant agencies. 
Data Analysis. Achievement of the main objectives in this research use financial feasibility analysis, with several indicators used, are:

Net Present Value (NPV).Kasmir (2007) suggests that Net Present Value (NPV) or net present value is a comparison between PV net cash and PV investment over the period of the investment.Ibrahim (2009), Suggests NPV could be calculated by the formula as follows:

$$
\underset{i=1}{\mathrm{nPV}}=\sum(\mathrm{Bt}-\mathrm{Ct})(\mathrm{DF})
$$

Information :

$\begin{array}{ll}\text { NPV } & =\text { Net Present Value } \\ \mathrm{DF} & =\text { Discount Factor } \\ \mathrm{Bt} & =\text { Benefit in year } \mathrm{t} \\ \mathrm{I} & =\text { the applicable interest rate; } \\ \mathrm{Ct} & =\text { Cost in year } \mathrm{t} \\ \mathrm{N} & =\text { Length of time period. }\end{array}$

Net Benefit Cost Ratio (Net B/C). Net Benefit Cost Ratio (Net $\mathrm{B} / \mathrm{C}$ ) is the ratio between the amount of net benefit and total cost based on relative cash value. Ibrahim (2009), suggests the value of Net B/C could be calculated by the equation as follows:

Net $\mathrm{B} / \mathrm{C}$ Ratio $=\frac{\text { Net Present Value }}{\text { Net Investment Value }}$.......(ii)

Internal Rate of Return (IRR). The Internal Rate of Return (IRR) is investment rate (yield rate), which describes the profit rate of a business or investment in percent (\%). Kuswandi (2007), suggests the level of investment (IRR) could be calculated by the following formula:

$N P V^{\prime} I R R=i^{\prime}+x \frac{\left(i '{ }^{\prime}-i^{\prime}\right)}{\text { NPV'- NPV', }}$

Information :

IRR = Internal Rate of Return

NPV $^{\prime}=$ Net Present Value First

NPV " = Net Present Value second

$\mathrm{I}^{\prime} \quad=$ The lowest Discount Factor

Ii' = Highest Discount Factor
Payback Period (PP). Minawati (2010), suggests the payback period shows how long (how many years) an investment would be returned. Payback period could be calculatedby the following formula:

$P P=n+\frac{a-b}{c-b} \times 1$ Year

Information:

$\mathrm{n}=$ The last year which a number of cash flows still could not fulfill the initial investment.

a = Amount of Initial Investment.

$\mathrm{b}=$ Total cumulative of cash flows in Year $\mathrm{n}$

c $=$ Total cumulative of cash flows in year $\mathrm{n}+1$.

Sensitivity Analysis. Sensitivity analysis is an analysis tool to find the feasibility status of investment (decision making) when the calculation factors being changed. Decisions could be sensitive when the value of parameters or factors of calculation, affecting investment decisions. The parameters that usually affect investments decision are the investment, cash flow, residual value, interest rate, taxrate and business feasibility level. (Minawati, 2010).

\section{RESULTS AND DISCUSSION}

Company History. CV. Rahayu founded by Mr. Ir. Ilham Ari Wibadi. CV. Rahayu established in 2013 and started to produce in early 2014. In the beginning, The Company's production still had a limit capacity ranging from 50 to 100 packs, with simple equipment. As time passes, demand for organic vegetables in the modern market continues to increase, while production capacity was still limited due to lack of capital and modern equipment. In the beginning 2014, Mr. Ari Wibadi updated his company intoComandeerVenotschop (CV). Mr. Ari Wibadi originally pioneered his own business, slowly Mr. Ari Wibadi made cooperation with the bank to invest some of the capital for his business 
development. Currently, CV. Rahayu is on advancement, this could be seen from the increasing number of consumers who are interested in organic vegetable products and also prove its existence through the achievements that have been achieved such as, Certificate of Organic Agriculture provided by the Institute of Indonesian Organic Farming Certification (INOFICE) And also the award as a champion in the competition organic food quality assurance system in 2016 Central Sulawesi.

Characteristics of The Company's Workforce.Characteristic of the Company's workforce as the main respondents in this research could be seen in Table 2 .

Age.The ability of work in producing the product determined by the age of respondents, because age will affect the physical ability and mindset in building a business. Respondents were used as a source of information on the CV. Rahayu, they were director of the company, the second respondent worked in the production process, the third respondent worked as the treasurer or the financial management section, the fourth respondent worked as the fertilizer factory supervisor, the fifth respondent worked as marketing, and the sixth respondent worked in the plantation.

Level of Education. Abilities and skills will always be influenced by experience, either educational experience or work experience. Mr. Ari Wibadi has a lot of experience. He was bachelor studentat Tridarma University Magelang, after that he worked as a production manager at PT. HASPAM for five years.

Table 2. Characteristics of labor

\begin{tabular}{cccr}
\hline $\begin{array}{c}\text { No. } \\
\text { Respondents }\end{array}$ & $\begin{array}{c}\text { Age } \\
\text { (year) }\end{array}$ & $\begin{array}{c}\text { Last } \\
\text { Education }\end{array}$ & $\begin{array}{c}\text { Jobs Experience } \\
\text { (Year) }\end{array}$ \\
\hline 1 & 50 & SP & 14 \\
2 & 23 & S.Hut & 1 \\
3 & 25 & SMP & 3 \\
4 & 30 & SMP & 1 \\
5 & 45 & SMP & 3 \\
6 & 31 & SMP & 3 \\
\hline Average & $\mathbf{4 0 . 8}$ & - & \multicolumn{4}{|c|}{} \\
\hline
\end{tabular}

Source: Primary data after processed, 2017.

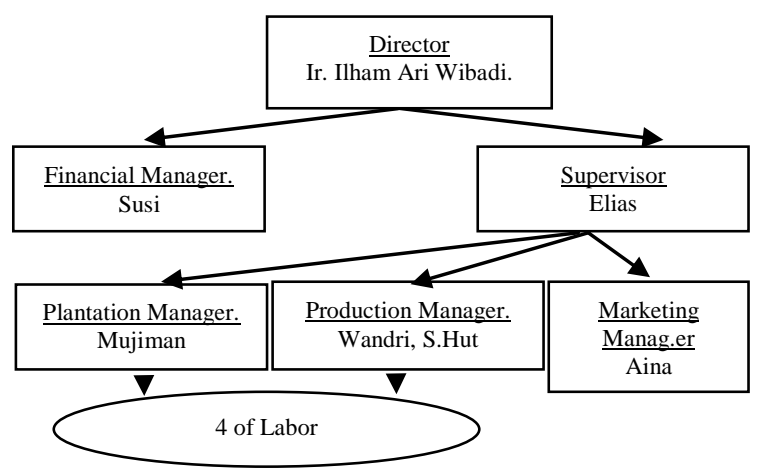

Figure 2. Organizational structure of CV. Rahayu

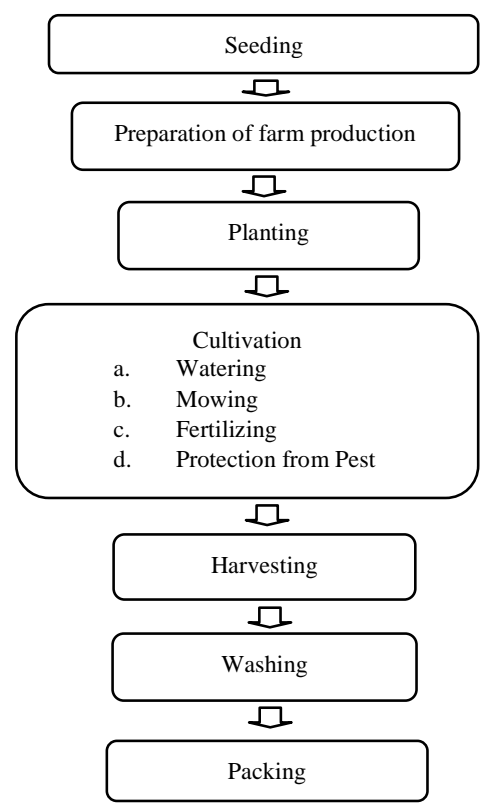

Figure 3. Production process of organic vegetable farming at $\mathrm{CV}$. Rahayu.

Organizational Structure CV. Rahayu. The structure is an arrangement or division of work positions in an organization (company) for sustainability organization's needs, especially the vision and mission of the organization itself. The structure of the organization at CV. Rahayu could be seen in Figure 2 as follows.

Chart of Organic Vegetable Cultivation Process at CV. Rahayu. Process of organic vegetable farming at $C V$. Rahayu inVillage of Sidera, District of Sigi Biromaru, Regency of Sigi could be seen clearly in the following picture. 
Table 3. The initial investment in the company of CV. Rahayu.

\begin{tabular}{clr}
\hline No. & Expenditure Types & $\begin{array}{r}\text { Value } \\
\text { (IDR) }\end{array}$ \\
\hline 1. & Loan Capital & $30,000,000$ \\
2. & Business License & 250,000 \\
3. & Machinery and & $456,560,000$ \\
4. & Lquipment & $350,000,000$ \\
\hline & Initial Investment & $836,810,000$ \\
\hline
\end{tabular}

Source: Primary data after processed, 2017.

Table 4. Production And Reception At Organic Vegetable Farming At CV. Rahayu Period Year 2014-2018.

\begin{tabular}{ccr}
\hline $\begin{array}{l}\text { Period } \\
\text { (Year) }\end{array}$ & $\begin{array}{c}\text { Production } \\
\text { (pack) }\end{array}$ & \multicolumn{1}{c}{$\begin{array}{c}\text { Revenue } \\
\text { (IDR) }\end{array}$} \\
\hline 2014 & 110,400 & $467,400,000$ \\
2015 & 118,800 & $507,360,000$ \\
2016 & 128,100 & $553,350,000$ \\
2017 & $137,964^{*}$ & $601,527,200$ \\
2018 & $148,586^{*}$ & $650,836,800$ \\
\hline
\end{tabular}

Source: Primary data after processed, 2017.

*Increase Estimation 7.7\%

Initial Investment in Company CV. Rahayu. Investment in CV. Rahayu are the form of lending capital from the Bank, purchasing Land and Building, purchasing of Business License, purchasing of supporting production tools such as disk mill, cultivator, granular, spray machine, hoe, spade, big knife, knife, grass knife, Arco, dap machine, nursery rack, water pipe, sprayer, nylon screen (press tool), wardrobe, printing equipment, and car. This could be seen in Table 3 .

Table 3 shows that the Company's initial investment expenditure is IDR. $836,810,000$. The largest investment was in the purchase of Machinery and Equipment with total expenses IDR.456,560,000 where some tools such as disk mill, cultivator, granular provided by the Provincial Government of Palu City. Land and Building purchases amounting to IDR.350, 000,000, obtained from loan proceeds through business credit in Bank. The lowest investment is the expenditure cost for the processing of business license worth IDR.250.000.
Table 5.Costs at CV. Rahayu period year 2014-2018

\begin{tabular}{crrcr}
\hline No. & $\begin{array}{r}\text { Period } \\
\text { (Year) }\end{array}$ & $\begin{array}{r}\text { Fixed } \\
\text { Cost } \\
\text { (IDR) }\end{array}$ & $\begin{array}{r}\text { Variable } \\
\text { Cost } \\
\text { (IDR) }\end{array}$ & $\begin{array}{r}\text { Total Cost } \\
\text { (IDR) }\end{array}$ \\
\hline 1. & 2014 & $1,514,000$ & $185,030,400$ & $186,544,400$ \\
2. & 2015 & $1,524,500$ & $205,471.800$ & $207,037,300$ \\
3. & 2016 & $1,534,500$ & $241,312,200$ & $242,846,700$ \\
4. & 2017 & $1,544,500$ & $264,851,880$ & $266,396,380$ \\
5. & 2018 & $1,554,500$ & $288,447,692$ & $290,002,192$ \\
\hline
\end{tabular}

Source: Primary data after processed, 2017.

Farm Production and Reception. Organic vegetable farming receipts sector is the total of revenue which has accepted from sales of organic vegetable products as result of the cultivation of the company CV. Rahayu itself. This could be seen in Table 4.

Table 4 shows the total revenue which hasaccepted by organic vegetable farming at CV. Rahayuis increasing every year. This situation has occurred from 2014 where the Company received IDR. $467,400,000$ until the year 2018, revenue rises up until IDR.650,836,800.

Cost. Components cost of the Company $\mathrm{CV}$. Rahayuis variable costs (the cost of providing Seeds, Fertilizers, Bio Pesticides, Fuel, Labor wages, Water, Supplementary materials) and fixed costs (Land Land tax, Vehicles, electricity and equipment depreciation costs). This could be seen in Table 5.

Table 5 shows that the total cost incurred by the company CV. Rahayu every year has increased. Increasing of the total cost from the year 2014 is IDR. $186,544,400$ until the year 2018 increased to IDR. 290,002,192.

Table 6. Net profit before tax at CV. Rahayu year 2014-2018.

\begin{tabular}{rrrr}
\hline $\begin{array}{r}\text { Period } \\
\text { (Year) }\end{array}$ & $\begin{array}{r}\text { Revenue } \\
(\text { IDR })\end{array}$ & $\begin{array}{r}\text { Total Cost } \\
(\text { IDR) }\end{array}$ & $\begin{array}{r}\text { Net Profit Before } \\
\text { Tax (IDR) }\end{array}$ \\
\hline 2014 & $467,400,000$ & $186,544,400$ & $280,855,600$ \\
2015 & $507,360,000$ & $207,037,300$ & $300,322,700$ \\
2016 & $553,350,000$ & $242,846,700$ & $310,503,300$ \\
2017 & $601,527,200$ & $266,396,380$ & $335,130,820$ \\
2018 & $650,836,800$ & $290,002,192$ & $360,834,608$ \\
\hline
\end{tabular}

Source: Primary data after processed, 2017. 
Net Profit Before Tax. Net profit before tax is income before lessened by tax or in other words positive value difference between total revenue and total cost in a certain period before tax deductions (Ilyas, 2015). This could be seen in Table 6 .

Table 6 shows that the net profit before tax in the company CV. Rahayu in the year 2014 is IDR. 280,855,600 to 2018 IDR. 360,834,608 Which defined as gross profit from revenue less to the total cost.

Net Profit After Tax. Tax is a liability company/business to be repaid (Ilyas, 2015). Net profit after tax represents the difference between net income before tax and tax of 15 percent of the net income before tax. This could be seen in Table 7 .

Table 7 shows that the net profit after tax in CV. Rahayu is increased from the year 2014 of IDR 238,727,260 until 2018 of IDR 306,709,417 which defined as net income or received before it added by depreciation. Increased in net profit after tax annually influenced by the increase in prices and the amount of production in the business.

Table 7. Net Profit After Tax At CV. Rahayu Period 2014-2018.

\begin{tabular}{rrrr}
\hline $\begin{array}{r}\text { Period } \\
\text { (Year) }\end{array}$ & $\begin{array}{r}\text { Net Profit } \\
\text { Before Tax } \\
\text { (IDR) }\end{array}$ & Tax 15\% & $\begin{array}{r}\text { Net Profit } \\
\text { (IDR) }\end{array}$ \\
\hline 2014 & $280,855,600$ & $42,128,340$ & $238,727,260$ \\
2015 & $300,322,700$ & $45,048,405$ & $255,274,295$ \\
2016 & $310,503,300$ & $46,575,495$ & $263,927,805$ \\
2017 & $335,130,820$ & $50,269,623$ & $284,861,197$ \\
2018 & $360,834,608$ & $54,125,191$ & $306,709,417$ \\
\hline
\end{tabular}

Source: Primary data after processed, 2017.

Table 8. Net cash flow in CV. Rahayu period year 2014-2018.

\begin{tabular}{crr}
\hline No. & Period (Year) & Net Cash Flow (IDR) \\
\hline 1 & 2014 & $355,482,460$ \\
2 & 2015 & $372,064,345$ \\
3 & 2016 & $380,683,005$ \\
4 & 2017 & $401,616,397$ \\
5 & 2018 & $423,464,617$ \\
\hline
\end{tabular}

Source: Primary data after processed, 2017.
Table 9. Financial feasibility analysis at CV. Rahayu period year 2014-2018

\begin{tabular}{cll}
\hline No & \multicolumn{1}{c}{ Criteria of Investment } & \multicolumn{1}{c}{ Value } \\
\hline 1 & Net Present Value (NPV) & IDR. 543,674,792 \\
2 & Net Benefit Cost Ratio (Net B/C) & 1.65 \\
3 & Internal Rate of Return (IRR) & $35.09 \%$ \\
4 & Payback Period PP) & 2.3 Year \\
\hline
\end{tabular}

Source: Primary data after processed, 2017.

Operational Cash Flow. Net cash inflows are the sum of net income after tax with depreciation. Net cash inflows in the company CV. Rahayu could be seen in Table 8.

Table 8 shows that net cash flow in the company CV. Rahayu from 2014 isIDR. $355,482,460$ until the year 2018 increased to IDR. 423,464,617. This means that CV. Rahayu has increased profits.

Financial Feasibility.The interest rate used for calculation in the company CV. Rahayu was 12 percent per year. Indicators that used in the assessment of the business whether the company feasible or unfeasibleto operate. Ibrahim (2010), A business is feasible to operate if it has NPV $>0, \mathrm{BCR}>1$ and IRR $>$ interest rate, then financially feasible to be executed. The calculation of the result of financial feasibility analysis could be seen in Table 9.

Based on the results of these calculations, Net Present Value (NPV) is IDR.543,674,792. This indicates that NPV is positive (NPV> 0), so it is declared feasible to run. Net Benefit Cost Ratio (Net $\mathrm{B} / \mathrm{C}$ ) obtained a value $1.65>1$. This means thatNet $\mathrm{B} / \mathrm{C}$ is more than 1 . So, this business is feasible to cultivate. Internal Rate of Return (IRR) obtained 35.09 percent. That is, the company is eligible to run because the rate of return is greater than the prevailing interest rate ( $\mathrm{i}=12$ percent), 12 percent ofdiscount factor is relevant with the prevailing bank's interest rate. The discount factor of $35.09 \%$, is used for future projection when the interest rate rises. Based on the calculation of Payback Period, the company has a payback period of 2.3 years. That is, in that period, the investment costs which has incurred could be returned. 


\begin{tabular}{|c|c|c|c|}
\hline $\mathrm{Ta}$ & 10. & $\begin{array}{l}\text { Calculation } \\
\text { Analysis } \\
\text { Vegetable Farm } \\
\text { Rahayu Period } \\
2018 .\end{array}$ & $\begin{array}{l}\text { Sensitivity } \\
\text { Organic } \\
\text { ing At CV. } \\
\text { Year 2014- }\end{array}$ \\
\hline $\begin{array}{l}\mathrm{N} \\
\mathrm{o}\end{array}$ & $\begin{array}{l}\text { Criteria of } \\
\text { Investment }\end{array}$ & $\begin{array}{r}\text { Decreasing of } \\
\text { Production } \\
30 \%\end{array}$ & $\begin{array}{r}\text { Increasing of } \\
\text { Cost } \\
\text { Production } \\
74 \%\end{array}$ \\
\hline 1 & $\begin{array}{l}\text { Net Present } \\
\text { Value }\end{array}$ & IDR.8.587.415 & IDR.7.276.181 \\
\hline 2 & $\begin{array}{l}\text { Net Benefit } \\
\text { Cost Ratio }\end{array}$ & 1,01 & 1.01 \\
\hline 3 & $\begin{array}{l}\text { Internal } \\
\text { Rate of } \\
\text { Return }\end{array}$ & $12,46 \%$ & $12,36 \%$ \\
\hline 4 & $\begin{array}{l}\text { Payback } \\
\text { Period }\end{array}$ & 3,6 Year & 3,6 Year \\
\hline
\end{tabular}

Source: Primary data after processed, 2017.

Sensitivity Analysis. Sensitivity analysis aims to test the feasibility of a business and see any effect that will occur due to changing circumstances. The simulation used in sensitivity analysis of organic vegetable farming at CV. Rahayu is a decrease in production (33 percent) due to pests and diseases and an increase in production costs (74 percent) due to volatility in market prices and labor wages. Calculation Sensitivity analysis could be seen in Table 10.

Table 10 shows the results of Sensitivity analysis calculations. Based on the results of these calculations, the value of Net Present Value (NPV) is IDR. 42,030,376 is greater than 0 , Net Benefit Cost Ratio (Net B/C) is 1.01 , is greater than 1. Internal Rate of Return (IRR) is 12.42 percent, greater than the initial interest rate of 12 percent and the payback period has a payback period of 3.46 years if a production decline of 33 percent and if the simulation is an increase in production costs of 74 percent, the value of Net Present Value (NPV) is IDR. 7,276,181 greater than 0 , Net Benefit Cost Ratio (Net B/C) is 1.01 , greater than 1, Internal Rate of Return (IRR) is 12.36 percent is greater than the initial interest rate of 12 percent and The payback period has a payback period of 3.6 years. These criteria indicate that the company CV. Rahayu is still feasible to operate. According to the results of the sensitivity analysis show that organic vegetable farming is a profitable business. This organic vegetable farming also shows the bright economic benefits in the future. So, this condition proves that organic vegetable farming has big enough potential to be developed.

\section{CONCLUSION AND SUGGESTION}

\section{Conclusion}

Based on the results and previous discussion, it could be concluded that:

1. Organic vegetable farming at CV. Rahayu, financially feasible to cultivate by looking at the results of calculations Net Present Value (NPV) is IDR.543.674.792, Net Benefit Cost Ratio $(\mathrm{Net} \mathrm{B} / \mathrm{C})$ is 1.65 , Internal Rate of Return (IRR) is 35.09 percent, the business has a payback period of 2.3 years.

2. The level of sensitivity in the company CV. Rahayu with the assumption thatorganic vegetables have beenattacked by pest and diseasewhich is resulting in a decrease in production until $33 \%$ and the calculation shows the NPV decreased to IDR.8,587,415, Net $\mathrm{B} / \mathrm{C}$ decreased to 1.01 , IRR decreased to 12.42 percent, the business has a payback period of 3.6 years. In the other hand, NPV will decrease to IDR. $7,276,181$, Net B/C decreased to 1.01 , IRR decreased to 12.36 percent, the business has a payback period of 3.6 years, if the assumption is an increase in production cost until 74 percent.

\section{Suggestion}

Based on the results above, then the suggestion for organic farming at company CV.Rahayuare:

1. CV. Rahayu should be cultivated continually because this business is 
financially very feasible to cultivate and have a very promising future.

2. CV. Rahayu should anticipate pests and diseases that could lead to decreased production of organic vegetables or should neutralize the amount of production input and wage labor because the company will lose if the production decreases greater than 33 percent or increased production costs greater than 74 percent.

\section{BIBLIOGRAPHY}

Balai Pusat Statistik Sulawesi Tengah. 2015. Produktivitas Petani Sayuran. Sulawesi Tengah.Diakses pada tanggal [24/09/2016]

Ibrahim, 2009. Studi Kelayakan Bisnis. Edisi Revisi. Rinaka Cipta. Jakarta

Ilyas, 2015. Analisis Kelayakan Finansial Pada Industri Jagad Sutera Di Kelurahan Kamonji Kecamatan Palu Barat Kota Palu. Jurnal Agroland Vol.22 (2) : 76 - 81

Kasmir, 2007. Studi Kelayakan Bisnis. Edisi-1. Penada Media. Jakarta

Kuswandi. 2007. Analisis Perekonomian Proyek. Andi Offset. Yogyakarta

Mayrowani, 2012. Pengembangan Pertanian Organik Di Indonesia. Jurnal Forum Penelitian Agro Ekonomi, Volume 30 (2) : 91 - 108

Minawati. 2010. Payback Period Analysis,[online], http://Payback period. Blogspot. Com. Diakses pada tanggal [24/09/2016]

Yantu, M.R Sisfayuni, Ludin dan Taufik. 2008 Komposisi Industri yang Membangun Sektor Pertanian Sulawesi Tengah. Jurnal Agroland Vol.3.(4):322-326. 